\title{
Vertical small scale variations of sorption and mineralization of three herbicides in subsurface limestone and sandy aquifer
}

\author{
Janniche, Gry Sander; Mouvet, C.; Albrechtsen, Hans-Jørgen
}

Published in:

Journal of Contaminant Hydrology

Link to article, DOI:

10.1016/j.jconhyd.2011.01.002

Publication date:

2011

Link back to DTU Orbit

Citation (APA):

Janniche, G. S., Mouvet, C., \& Albrechtsen, H-J. (2011). Vertical small scale variations of sorption and mineralization of three herbicides in subsurface limestone and sandy aquifer. Journal of Contaminant Hydrology, 123(3-4), 167-177. https://doi.org/10.1016/j.jconhyd.2011.01.002

\section{General rights}

Copyright and moral rights for the publications made accessible in the public portal are retained by the authors and/or other copyright owners and it is a condition of accessing publications that users recognise and abide by the legal requirements associated with these rights.

- Users may download and print one copy of any publication from the public portal for the purpose of private study or research.

- You may not further distribute the material or use it for any profit-making activity or commercial gain

- You may freely distribute the URL identifying the publication in the public portal 
$19{ }^{*}$ Corresponding author

20 Telephone: (+45) 45251459

21 Fax: (+45) 45932850

22 Email: gsf@env.dtu.dk 
Vertical variation in sorption and mineralization potential of mecoprop (MCPP),

isoproturon and acetochlor was investigated at low concentrations ( $\mu$ g-range) at the cm-scale in unsaturated sub-surface limestone samples and saturated sandy aquifer samples from an agricultural catchment in Brévilles, France. From two intact core drills, four heterogenic limestone sections were collected from 4.50-26.40 m below surface (mbs) and divided into 12 sub-samples of 8-25 cm length, and one sandy aquifer section from 19.20-19.53 m depth divided into 7 sub-samples of 4-5 cm length. In the sandy aquifer section acetochlor and isoproturon sorption increased substantially with depth; in average $78 \%$ (acetochlor) and 61 \% (isoproturon) per $5 \mathrm{~cm}$. Also the number of acetochlor and isoproturon degraders (mostprobable-number) was higher in the bottom half of the aquifer section (93->16 000 /g) than in the upper half (4-71 /g). One $50 \mathrm{~cm}$ long limestone section with a distinct shift in color showed a clear shift in mineralization, number of degraders and sorption: In the two brown, uppermost samples, up to $31 \%$ mecoprop and up to $9 \%$ isoproturon was mineralized during 231 days, the numbers of mecoprop and isoproturon degraders were 1300 to >16 000 /g, and the sorption of both isoproturon and acetochlor was more than three times higher, compared to the two deeper, grayish samples just below where mineralization $(\leq 4 \%)$ and numbers of degraders (1-520 /g) were low for all three herbicides. In both unsaturated limestone and sandy aquifer, variations and even distinct shifts in both mineralization, number of specific degraders and sorption were seen within just 4-15 cm of vertical distance. A simple conceptual model of herbicides leaching to groundwater through a $10 \mathrm{~m}$ unsaturated limestone was established, and calculations showed that a $30 \mathrm{~cm}$ active layer with the measured sorption and mineralization values hardly impacted the fate of the investigated herbicides, whereas a total thickness of layers of $1 \mathrm{~m}$ would substantially increase natural attenuation. 
Keywords: Isoproturon; mecoprop (MCPP); acetochlor; degradation; pesticide; fate.

51

\section{Introduction}

Pesticides and their degradation products are often detected in surface water and groundwater (Battaglin et al., 2000; Kolpin et al., 1997; Thorling, 2009) even above the EU groundwater guideline of $0.1 \mu \mathrm{g} / \mathrm{L}$ (European Parliament and Council, 2006) and they are in this way posing a substantial risk to drinking water resources. This diffuse pesticide pollution has become one of the major environmental challenges for using groundwater as drinking water, and to predict the fate of pollutants in groundwater the entire catchment has to be considered (Turner et al., 2006).

Knowledge on sorption and degradation is essential for evaluating risks of pesticides contamination of groundwater since these two processes are the major drivers in natural attenuation. Degradation of pesticides is often considered to decrease with depth (Fomsgaard, 1995) but degradation can be faster in sub-soil than in top-soil (Mills et al., 2001). Sorption may also decrease with depth because of decreasing organic matter content which on the other hand may increase the bioavailability (Bending and Rodriguez-Cruz, 2007). Spatial variability in herbicide degradation and sorption has mainly been studied in topsoil or the upper meter of agricultural fields (e.g. Bending et al., 2001, 2003; Charnay et al., 2005; Jacques et al., 1999; Fredslund et al., 2008; Vinther et al., 2008; Walker et al., 2001, 2002) and even at the millimeter scale (Gonod et al., 2003).

Although several studies have focused on pesticide fate in subsurface materials and aquifers only few have studied the vertical variability in these environments (Albrechtsen et al., 2001; Charnay et al., 2005; Coquet et al., 2004; Johnson et al., 2000; Larsen et al., 2000; Wood et al., 2002). Even fewer have considered chalk or limestone, probably because of the complexity and the difficulties in sampling such geological settings. Vertical variation in limestone of atrazine mineralization was investigated in seven samples collected from 4.6- 
10.0 mbs (Charnay et al, 2005), and small-scale vertical variation in isoproturon degradation was investigated in chalk (four 5-cm core sections from 4.42-4-88 mbs) (Johnson et al., 2000), but since degradation was negligible in both studies, their contribution to insight in the spatial variation was limited. In limestone (Charnay) the sorption of atrazine, isoproturon and metamitron varied vertically only to a limited degree in 10 out of 11 samples (3-12 mbs), but one sample had significantly higher $\mathrm{K}_{\mathrm{d}}$-values which could not be explained by the content of clay or organic matter (Coquet et al., 2004). Hence, only vertical variation in sorption but not in degradation of herbicides in subsurface carbonate rock was reported.

If sediment layers with increased mineralization could be identified it would be a step towards better understanding the interaction between sediment and biodegradation, which may improve the predictions and modeling of herbicides fate. Such sediment layers may in fact be "ecotones" where the microbial activity is high, found at the interface between different lithological layers (Goldscheider et al., 2006).

Spatial variability at the cm-scale in natural mineralization potential and sorption capacity of herbicides has to our knowledge not been studied before in deep subsurface samples (below $5 \mathrm{mbs}$ ), and especially not in limestone. The aim of this current work was to investigate i) if there is a vertical small scale spatial variability in sorption and in mineralization potential of the herbicides mecoprop, isoproturon and acetochlor in sediments from subsurface limestone and sandy aquifer; ii) if the variations could be related to a simple geochemical parameter; and iii) at which such a variation occurs and becomes important for the whole system.

\section{Materials and Methods}

\subsection{Sediment sampling and characterization}

Sediment was collected as intact cores in 2005 (Janniche et al., submitted), from a 4.5 $\mathrm{km}^{2}$ agricultural catchment with diffuse pesticide pollution. The unsaturated zone consists of 
lutetian heterogeneous limestone, and the sandy aquifer is unconfined and aerobic with the

101 groundwater table between 13.3 and 41.9 m below surface (mbs) (Morvan et al., 2006). Five

102 sections were collected from two cores (Pz14 and Pz17c); four from the unsaturated

103 limestone (sections A to D) and one from the saturated sand (section E). The sections were sampled from 4.50 to 26.40 mbs (Table 2). The sections were further divided vertically in 4 to $25 \mathrm{~cm}$ long subsamples. The four limestone sections were selected based on a visual inspection: three with rather consistent color and texture over depth, and one section with a distinct shift in color that divided the section in a brownish upper part and a grayish lower part. The sand section had a color gradient over the section length; ranging from brown in the upper samples to dark grey especially in the two bottom samples. Water content of the sediment samples was measured as weight loss after $24 \mathrm{~h}$ at 105 (Bigham et al., 1996). Total inorganic carbon (TIC) was calculated as the difference between total carbon content (TC) and Total organic (TOC). TOC and TC were measured based on the method by Heron et al. (1997) by a total elemental carbon analyzer (LECO CS-225) in triplicates $(0.2000 \mathrm{~g})$ where carbonates were removed by adding $2 \mathrm{~mL} 6 \%$ sulphurous acid $\left(\mathrm{H}_{2} \mathrm{SO}_{3}\right)$ six times to ensure that no bubble formation as released $\mathrm{CO}_{2}$ could be observed.

117 Grain size (only for unconsolidated samples) was characterized by sieving (sieves of 0.063-

$1182.0 \mathrm{~mm}$ ) and, for the particles below $63 \mu \mathrm{m}$, by particle distribution (Sedigraph 5100,

119 Micromeritics Gemini). The specific surface area was measured by Multipoint $\mathrm{N}_{2}$-BET analysis (Micromeritics, Gemini III 2375 surface area analyzer), after being outgassed

121 (Micromeritics, FlowPrep 060 Degasser) for $4 \mathrm{~h}$ at $70{ }^{\circ} \mathrm{C}$.

\subsection{Herbicides} mecoprop is a hydrophilic phenoxy acid with a $\mathrm{pK}_{\mathrm{a}}$ value of 3.78 and at near-neutral $\mathrm{pH}$ it is 
site to a wide extent. The experiments were carried out with [Ring- $\left.{ }^{14} \mathrm{C}\right]$-pesticides (Table 1 ).

127 In the MPN also unlabelled acetochlor with $99.4 \%$ purity was used.

128 Table 1

\subsection{Sorption investigations}

Sorption was investigated by a batch equilibrium technique based on the OECD guideline 106 (1993) at initial pesticide concentrations of 1 and $50 \mu \mathrm{g} / \mathrm{L}$. Stock solutions of

${ }^{14} \mathrm{C}$-labeled pesticide was prepared with ${ }^{14} \mathrm{C}$-labelled pesticides in sterile filtered MilliQ water (Clausen et al., 2001). The sediment samples were crushed (only limestone), freeze-dried and sieved ( $<2 \mathrm{~mm}$ ) (Madsen et al., 2000). The investigations were carried out in glass tubes (10 $\mathrm{mL}$ ) with Teflon caps at $10^{\circ} \mathrm{C}$ in the dark and previous tests excluded adsorption on those materials (Madsen et al., 2000). The water from the Brévilles Spring in the catchment was used as equilibrium liquid in the investigations as representative for the groundwater after treatment with activated carbon to remove pesticides and sterile filtering. Triplicate $5 \pm$ $0.0005 \mathrm{~g}$ of sediment was pre-equilibrated with $4 \mathrm{~mL}$ sterile filtered $(0.2 \mu \mathrm{m}$ Minisart, Sartorius) water for $20 \mathrm{~h}$, then $1 \mathrm{~mL}$ pesticide solution was added resulting in an initial concentration of 1 or $50 \mu \mathrm{g} / \mathrm{L}$ (these low concentrations were chosen to mimic environmentally relevant concentrations), and each test tube was placed in a vertical rotator.

143 Based on preliminary investigations (Mouvet et al., 2004) $168 \mathrm{~h}$ (for mecoprop and acetochlor) or $336 \mathrm{~h}$ (for isoproturon) was sufficient to reach equilibrium, and after this equilibrations time the suspension was centrifuged and $1 \mathrm{~mL}$ of supernatant collected for quantification of ${ }^{14} \mathrm{C}$-activity (Clausen et al., 2001). Reference samples were prepared in

147 triplicate without sediment but otherwise handled identically to the other samples. The

148 amount of adsorbed pesticide was calculated as the difference between the ${ }^{14} \mathrm{C}$-activity in the 149 supernatant solution at equilibrium and the ${ }^{14} \mathrm{C}$-activity in the reference solution (detection 150 limit of $1 \%)$. To check if the herbicides were degraded during the sorption equilibration 1 $151 \mathrm{~mL}$ of supernatant was transferred to a "double-vial” system; $20 \mathrm{~mL}$ polyethylene 
152 scintillation vial containing a $6 \mathrm{~mL}$ scintillation vial with $1 \mathrm{~mL} 2.5 \mathrm{M} \mathrm{NaOH}$ to trap ${ }^{14} \mathrm{CO}_{2}$

153 after acidification of the subsample (0.1 mL 37\%). The inner-vial was removed after 48

154 hours, added scintillation cocktail and the ${ }^{14} \mathrm{C}$-activity in e.g. the ${ }^{14} \mathrm{CO}_{2}$-fraction was

155 quantified.

\subsection{Mineralization}

Mineralization was investigated in laboratory batch incubations set up under unsaturated or saturated conditions depending on the origin of each sample (Janniche et al., submitted) and incubated aerobically in the dark at $10^{\circ} \mathrm{C}$ for up to 251 days. Autoclaved (20 min at 1.5 bars and $120^{\circ} \mathrm{C}$ three times with one-day intervals) control incubations and duplicates were set up for selected sediments.

Unsaturated sediment was set up with 40 g (wet weight) sediment (limestone samples were "gently" crushed prior to a size that could pass the bottleneck with a diameter of $3 \mathrm{~cm}$ ) in a $100 \mathrm{~mL}$ DURAN ${ }^{\circledR}$ bottle with Teflon inlayer caps and spiked with $0.5 \mathrm{~mL}$ of pesticide stock solution to reach initial concentrations of $1 \mu \mathrm{g} / \mathrm{kg}$. The produced ${ }^{14} \mathrm{CO}_{2}$ was trapped in a test tube placed inside each bottle with $2 \mathrm{~mL} 0.5 \mathrm{M} \mathrm{NaOH}$. When sampled, the sodium hydroxide was replaced and mixed with $10 \mathrm{~mL}$ scintillation fluid and the ${ }^{14} \mathrm{C}$-activity quantified. The bottles were left open for 5 minutes in a laminar flow bench to replenish oxygen. Mineralization was calculated as the cumulated ${ }^{14} \mathrm{CO}_{2}$ evolution over time as a percentage of initial ${ }^{14} \mathrm{C}$-pesticide e.g. ${ }^{14} \mathrm{CO}_{2} /{ }^{14} \mathrm{C}_{0}(\%)$. in a $118 \mathrm{~mL}$ glass serum bottle, sealed with a $1 \mathrm{~cm}$ thick butyl rubber stopper and crimp caps.

$1731 \mathrm{~mL}$ stock solution of ${ }^{14} \mathrm{C}$ labeled pesticide was added through the stopper resulting in an 174 initial concentration in the water phase of approximately $1 \mu \mathrm{g} / \mathrm{L}$ of each pesticide. As for the 175 sorption investigations, the groundwater was collected from the Brévilles spring, treated with activated carbon and sterile filtered. When sampling, $2 \mathrm{~mL}$ filtered $(0.2 \mu \mathrm{m}$ PTFE-filter; 
that then was captured by $\mathrm{NaOH}$ in a"double-vial” system as described earlier. Pesticide content over time was calculated as the fraction of initial ${ }^{14} \mathrm{C}$-pesticide corrected for pesticide removed during sampling. Mineralization over time was calculated as ${ }^{14} \mathrm{CO}_{2}$ evolution (corrected for loss to headspace) as a percentage of the corrected initial ${ }^{14} \mathrm{C}$-pesticide e.g. ${ }^{14} \mathrm{CO}_{2} /{ }^{14} \mathrm{C}_{0}(\%)$

\subsection{Enumeration of specific pesticide degraders}

The specific pesticide degraders was enumerated by a modified (Janniche et al., submitted) most-probable-number method $\left({ }^{14} \mathrm{C}-\mathrm{MPN}\right)$ (Lehmicke et al., 1979). For each pesticide, sediment samples were mixed with pyrophosphate-buffer $\left(1.2 \mathrm{mM} \mathrm{Na}_{4} \mathrm{P}_{2} \mathrm{O}_{7}, \mathrm{pH}=\right.$ 7.0) and 10-fold serial dilutions $\left(10^{0}-10^{-4}\right)$ were prepared from which five replicates where made, resulting in 25 MPN-tubes to achieve 1 enumeration. The dilutions were added a complex mineral medium (ISO 7827, 1984) with $\mathrm{pH}=6.8$ and $25 \mu \mathrm{g} / \mathrm{L}{ }^{14} \mathrm{C}$-mecoprop or ${ }^{14} \mathrm{C}$ isoproturon, or $10 \mu \mathrm{g} / \mathrm{L}{ }^{14} \mathrm{C}$-acetochlor and $20 \mu \mathrm{g} / \mathrm{L}$ acetochlor (due to late receipt of the acetochlor isotope the MPN-assay was set up with unlabeled acetochlor, and 3 month later was isotope added). The MPN-tubes were incubated $11-23$ months in the dark at $15{ }^{\circ} \mathrm{C}$ and the ${ }^{14} \mathrm{CO}_{2}$ evolved during incubation was trapped and measured by liquid scintillation counting. Controls were set up with sterile pyrophosphate-buffer without sediment suspension.

The MPN values and $95 \%$ confides intervals were calculated by the computer software MPN calculator (Curiale, 2000) based on the number of positive scored tubes in each of the five dilutions. A positive score means that the MPN-tube contained bacteria capable of mineralizing the specific herbicide. The MPN-tubes were scored positive if the trapped ${ }^{14} \mathrm{CO}_{2}$ was greater than the average of 10 sterile controls plus three times the standard deviation (Lehmicke et al. 1979). The MPNs containing mecoprop were scored as positive if the radioactivity in the basetrap was $>2.7 \%$ of the initially added amount of labeled; the values for isoproturon was $1.2 \%$ and $2.0 \%$ for acetochlor. 


\section{Results and Discussion}

\subsection{Sediment characterization}

Core sections A-D were taken from the heterogeneous unsaturated limestone and section E from the sandy aquifer (Table 2). The heterogeneous limestone samples had relatively low values of total inorganic carbon (TIC): 17-69 \% $\mathrm{CaCO}_{3}$ with the lowest values found in the samples with marls. Though high TIC content may interfere with the total organic carbon (TOC) measuring, the results have high reproducibility, and are equivalent to reports for similar settings, e.g. 0.1-2.9 \% TOC in limestone and 0-5.9 \% in marlstone (Coquet et al., 2004), who also reported $\mathrm{CaCO}_{3}$ content of $69-88 \%$ in limestone and $69-74 \%$ in marlstone. The heterogeneous nature of our limestone may explain the relatively low TIC content compared to samples of pure limestone.

The limestone sections from Pz14 (A and C) had in general higher contents of water, TOC and TIC but a lower specific surface area than those from Pz17c (B and D). Besides differences observed between sections, differences were also observed at cm scale within a given section. Thus, limestone section D had a clear visual color shift and a clear shift in specific surface area with much higher specific surface area in the two uppermost samples (D1 and D2) compared to the two bottom samples (D3 and D4). Also the TIC content shifted with a lower TIC content in D1 and D2 compared to D3 and D4 expressing more pure limestone in D3-D4 than in D1-D2. Besides, TOC was much lower in the first sample, D1, than the other samples D2-D4 within this section.

Aquifer section (E) from Pz17c had high specific surface area but low TOC (Table 2). The color gradually changed across the whole section from brownish to grayish and TIC slightly increased with depth; samples E1 and E2 had approximately half the TIC content of E3-E7.

In summary, the five core sections represented two major geological settings and different limestone settings; the limestone cores varied in textures, but the geology of the 
individual sections was very similar at the macro geological scale. Section D and E had clear small-scale variations at the micro scale in the sediment characterization parameters.

Table 2

\subsection{Sorption}

The sorption investigations included two concentrations (1 and $50 \mu \mathrm{g} / \mathrm{L}$ ) and linear

distribution coefficients $\left(\mathrm{K}_{\mathrm{d}}\right)$ were calculated. The different concentrations only to a limited degree affected the $\mathrm{K}_{\mathrm{d}}$-values (Fig. 1), and only noteworthy for isoproturon in the aquifer samples E3, E4 and E5, where sorption at the high concentration surprisingly was clearly higher $(0.78-1.69 \mathrm{~L} / \mathrm{kg})$ than at the low concentration $(0.52-0.87 \mathrm{~L} / \mathrm{kg})$. However, all isoproturon $\mathrm{K}_{\mathrm{d}}$ values from section $\mathrm{E}$ followed the same trend of increased sorption over depth (Fig. 1).

\section{$242 \quad$ Fig. 1}

In limestone samples, sorption was in general low for all three herbicides and so was the standard deviation reflecting high reproducibility (Fig. 1 A-D). In all limestone sections, 245 isoproturon sorption was at or below the detection limit of $0.010 \mathrm{~L} / \mathrm{kg}$ except in section D $246\left(\mathrm{~K}_{\mathrm{d}}: 0.03-0.25 \mathrm{~L} / \mathrm{kg}\right)$. These findings are within the range reported for isoproturon sorption to 247 limestone and chalk: <0.01-0.55 L/kg (Besien et al., 2000; Coquet et al., 2004; Johnson et al., 248 1998; Madsen et al., 2000; Mouvet et al., 2004). The $K_{d}$ values for acetochlor in the 249 limestone was $<0.01-0.34 \mathrm{~L} / \mathrm{kg}$; literature $\mathrm{K}_{\mathrm{d}}$ values for acetochlor, in the range of 0.48-7.11 250 L/kg (Hiller et al., 2009; Lengyel and Foldenyi, 2003; Ma et al., 2004), are predominantly 251 reported for topsoil which explains their substantially higher $\mathrm{K}_{\mathrm{d}}$ values. The mecoprop sorption to limestone was also low $(\leq 0.15 \mathrm{~L} / \mathrm{kg})$ and in the range $(0-0.17 \mathrm{~L} / \mathrm{kg})$ reported in 253 the literature for chalk and limestone (Clausen et al., 2001; Kristensen et al., 2001; Madsen et 254 al., 2000). 
with higher specific surface area, and lower TOC than in the other limestone samples (Table

2). This indicated that isoproturon and acetochlor sorption in heterogenic limestone to a higher degree was controlled by mineralogy than by organic carbon content. Isoproturon sorbs to kaolinite, but not to quartz, calcite, aluminia (Clausen et al., 2001) or iron oxides

260 (Clausen and Fabricius, 2001), and then sorption is strongly related to the content of organic matter and clay (Coquet et al., 2004; Madsen et al., 2000). This supports that the increased isoproturon sorption was caused by the increased clay content within the limestone marls. Sorption of acetochlor is likely to be controlled by the same parameters, but comparable literature data are limited for acetochlor sorption in subsurface sediments, low in TOC. Sorption of mecoprop was not increased in the same sections as isoproturon and acetochlor because the sorption mechanisms of the anionic mecoprop differ from the nonionic herbicides isoproturon and acetochlor; mecoprop sorbs to positive sites on the mineral surface (Clausen et al., 2001).

In sandy aquifer samples sorption was in general substantial for acetochlor (0.25-5.12 $\mathrm{L} / \mathrm{kg}$ ) and isoproturon (<0.01-1.69 L/kg) except in E1 (Fig. 1), whereas mecoprop sorption was very low $(\leq 0.12 \mathrm{~L} / \mathrm{kg})$ in the two investigated samples (E2 and E3). The sorption could not be explained solely by variations in the investigated geochemical parameters (clay content, organic and inorganic carbon content). The grayish color observed in the bottom two

274 subsamples (E6 and E7) of the aquifer section indicated reduced conditions which may, 275 however, explain the increased sorption capacity over depth because reduced organic matter induce a more hydrophobic surface whereto nonionic compounds better sorbs (Clausen et al., 2004). $K_{d}$ values of 0-0.4 L/kg have been reported for mecoprop sorption onto sand (Madsen et al., 2000; Pedersen, 2000; Tuxen et al., 2000), and our finding is within this range. $K_{d}$ 
al., 2000; Pedersen, 2000; Tuxen et al., 2000); our results are in close agreement with these

281

282

283

284

285

286

287

288

289

290

291

292

293

294

295

296

297

298

299

300

301

302 values.

\subsection{Mineralization potential}

Mecoprop, isoproturon and acetochlor degraders were detected in many samples (Fig. 2) which indicated a degradation potential of these compounds in the catchment. Furthermore, this suggested that the catchment was polluted with all three herbicides since another study only detected phenoxy acid (mecoprop, dichlorprop and 2,4-D) degraders in the part of the aquifer exposed to phenoxy acids $(<40 \mu \mathrm{g} / \mathrm{L}$ ) but not in the upstream pristine aquifer (de Lipthay et al., 2003). The number of mecoprop degraders found in our investigation was at same level as observed by de Lipthay et al. (2003) but the number of isoproturon degraders was higher than reported by Bending \& Rodriguez-Cruz (2007).

Fig. 2

In all the 12 limestone samples mineralization of acetochlor was below $2 \%$. Isoproturon was mineralized (up to 9\%) in D1 and D2; in the remaining samples $<1 \%$ was mineralized. 19-31 \% mecoprop was mineralized in D1 and D2 and $4 \%$ in D3 and C4 (average of two replicates with 6 and $2 \%$ ). The other samples exhibited mecoprop mineralization below $1 \%$. The number of degraders was in general high in section D, but also in sample C3 the number of isoproturon degraders was extremely high (>16 000 /g). Some samples had high number of degraders without subsequent high mineralization (e.g. D1 (acetochlor), C3 (isoproturon)). In the sandy aquifer (E), mecoprop was also mineralized substantially; 10-22\% was recovered as ${ }^{14} \mathrm{CO}_{2}$ with only 49-790 /g mecoprop degraders. The mineralization of both isoproturon (1-5\%) and acetochlor (3-6\%) was markedly lower than for mecoprop, despite higher numbers of isoproturon (27-2 200 /g) and acetochlor degraders (4-16 000 /g).

\subsection{Small scale variability}

The 19 samples from the 5 sections fell into 3 different cases: 1) In unsaturated limestone sections A, B and C sorption, mineralization and MPN were in general limited for 
all three studied herbicides (one exception was mecoprop sorption which was $\leq 0.01 \mathrm{~L} / \mathrm{k}$ in sample A1 but 10-fold higher (0.11-0.15 L/kg) in A2 - the sample just below ). 2)

Unsaturated limestone section D clearly showed small scale variations with a clear shift in sorption, mineralization and MPN. 3) Sandy aquifer section E had evident small scale variation in sorption but without a clear shift; it was rather a gradient, but also with variation in especially MPN.

\subsubsection{Unsaturated limestone from section D}

Sorption of isoproturon and acetochlor, and mineralization of mecoprop and acetochlor as well as number of mecoprop and acetochlor degraders were increased in the upper part of section D (Fig. 1 and 2). A shift in color divided the section in two: the two brownish uppermost samples (D1 and D2) with high sorption (isoproturon: 0.17-0.25 L/kg and acetochlor: 0.22-0.34 L/kg), mineralization (mecoprop: 19-31 \% and isoproturon: $9 \%$ ), and number of herbicide degraders (mecoprop: 1300-1400 /g and isoproturon: 4300->16000 /g) and on the other hand the grayish, lower samples (D3 and D4) with lower sorption (isoproturon: 0.03-0.07 L/kg and acetochlor: $<0.01-0.11 \mathrm{~L} / \mathrm{kg}$ ), mineralization (mecoprop: 0.5-4 \% and isoproturon: 0.2-0.5 \%), and number of herbicide degraders (mecoprop: 1-6 /g and isoproturon: 3-520 /g). Already after 14 days of incubation the mineralization in D1 and D2 was noticeable higher than in D3 and D4 (Fig. 3). Furthermore, the ${ }^{14} \mathrm{CO}_{2}$ evolution in D4 was as low as in the autoclaved incubations with sediment from D1-D4. Hence, a clear small scale shift in sorption and mineralization potential within only $25 \mathrm{~cm}$ was evident in the limestone.

Fig. 3

\subsubsection{Sandy aquifer section $E$}

In the sandy aquifer samples sorption was low in the two uppermost samples, and 
in the sandy aquifer section (E). Also the isoproturon sorption increased gradually with depth

332 (in average $61 \%$ pr $5 \mathrm{~cm}$ ) in the sandy aquifer (E) and hence the small scale variance in acetochlor and isoproturon sorption within these $33 \mathrm{~cm}$ was substantial. Despite the acetochlor mineralization in the sandy aquifer was rather constant, the number of acetochlor degraders increased dramatically in the three bottom samples; from 4-9/g in E1-E4 to 120-16 000/g in E5-E7. Also the number of isoproturon degraders was higher in the bottom samples (93-2 200/g in E4-E7) than in the top samples (27-71/g in E1-E3), and mineralization was faster in E1-E4 (2-5 \%) than in E5-E7 ( $<1 \%)$. For mecoprop however, the middle part (E3E5) had the highest number of degraders; 490-790/g compared to 49-93/g, and mineralization was also substantially faster in E5 (22 \%) compared to the rest of the aquifer (10-15\%). Mineralization of acetochlor and isoproturon in the saturated sandy aquifer samples (Fig. 2) could very well be negatively affected by the increased sorption with depth, leaving less herbicide available for mineralization, and could explain the lack of faster mineralization, despite very high number of degraders in some samples. This inverse relationship between sorption strength and mineralization was reported for MCPA (Jensen et al., 2004). This could explain why isoproturon was mineralized (1.7-4.7 \%) in the uppermost samples (E2-E4) but not in the bottom samples ( $<1 \%$ in E5-E7). However, acetochlor which sorbed stronger did not follow that trend.

Conclusively, sorption and mineralization potential varied substantially within just a few $\mathrm{cm}$ in both limestone and sand. These small scale variations were found in sections with shifts in color, but could not be strongly related to the investiaged geochemical parameters.

\subsection{Importance of an active limestone layer on groundwater} contamination

The investigated four limestone sections revealed an overall picture of very low herbicide sorption and mineralization, except in the upper two $15 \mathrm{~cm}$ samples of section $\mathrm{D}$, where both sorption and mineralization potential was increased. This section contained marls 
357

358

359

360

361

362

363

364

365

366

367

368

369

370

371

376

(Table 2) and upper Lutetian marly layers are ubiquitous in the catchment, and may reduce the flow rate and subsequent solute transport (Gutierrez and Baran, 2009). This marly layer with increased water content may be an environment favoring microbial activity.

To evaluate the relative impact on mecoprop, isoproturon and acetochlor of such an active layer with respect to sorption and mineralization in the unsaturated limestone a simple conceptual model was set up. Although both matrix flow and fracture flow may occur in heterogeneous unsaturated limestone matrix flow has in several studies shown to be predominant in deep groundwater sites and at steady-state flow (Haria et al., 2003; Mathias et al., 2005; Wellings, 1984). Slow transfer velocities of 0.5 to $1 \mathrm{~m} / \mathrm{yr}$ have earlier been determined for our catchment based on profiles of water contents, tritium activities, and nitrate concentrations (Gutierrez and Baran, 2009). We therefore assumed that the dominant flow occurred in matrix in the calculations of the conceptual model consisting of a $10 \mathrm{~m}$ unsaturated heterogeneous limestone profile with an active layer of a certain thickness $\left(\mathrm{x}_{\mathrm{a}}\right)$. Sorption and mineralization was confined to this active layer and hence microbial activity is assumed in the matrix. Such an active laver with sorption will cause retardation (R) of the herbicides which was calculated assuming matrix flow as:

$$
R=\frac{x_{w}}{x_{s}}=\frac{v_{w}}{v_{s}}=\frac{\rho_{b}}{\varepsilon} K_{d}+1
$$

where $\mathrm{v}_{\mathrm{s}}$ is the solute velocity $[\mathrm{m} / \mathrm{y}], \rho_{\mathrm{b}}$ is the bulk density $[\mathrm{kg} / \mathrm{L}]$ calculated as $\rho_{\mathrm{b}}=(1-\varepsilon) \rho, \varepsilon$ is the porosity [-], and $\mathrm{K}_{\mathrm{d}}$ is the linear sorption coefficient [L/kg]. The delay in break through due to sorption of the herbicides in the active layer was calculated as:

$$
\text { Delay }=\frac{x_{a}}{v_{w}}(R-1)
$$

Mineralization of herbicide will reduce the risk of groundwater contamination in accordance with the observed mineralization patterns (Fig. 3) and the removal of herbicides due to mineralization was calculated based on first order mineralization kinetics as: 


$$
\text { removal }=\left(1-\exp \left(k \frac{x_{a} R}{v_{w}}\right)\right) \times 100 \%
$$

382

383

384

385

386

387

388

389

390

391

392

393

394

395

396

397

398

399

400

401

402

403

404

405

where $\mathrm{k}$ is the first order mineralization constant. $\mathrm{K}_{\mathrm{d}}$-values and $\mathrm{k}$-values are mean values as observed for D1 and D2 (Fig. 1 and 2). Unfortunately, density ( $\rho)$ and porosity ( $\varepsilon$ ) were not measured specifically for D1 and D2 due to lack of sample material but in 7 other samples from the catchment; $\rho$ ranged from 2.69 to $2.73 \mathrm{~kg} / \mathrm{L}$ and $\varepsilon$ from 0.08 to 0.37 (Janniche et al., submitted). We have used the mean value of 0.18 for $\varepsilon$ and $2.72 \mathrm{~kg} / \mathrm{L}$ for $\rho$ in this simple conceptual model calculation which results in a $\rho_{\mathrm{b}}$ of $2.2 \mathrm{~kg} / \mathrm{L}$. If a lower porosity $(\varepsilon)$ and hence a higher bulk density $\left(\rho_{\mathrm{b}}\right)$ was applied the retardation would have increased, and vice versa.

Three scenarios were set up: 1) a reference scenario with no active layer, 2) an active layer of $30 \mathrm{~cm}$ thickness, and 3) an active layer of $1 \mathrm{~m}$ thickness (Fig. 4). In the reference scenario the herbicides are transported at the same velocity as water $\left(\mathrm{v}_{\mathrm{w}}\right)$, and with a water velocity of $1 \mathrm{~m} / \mathrm{yr}$ it will take 10 years before breakthrough of the herbicides through the 10 m long profile. Presence of a $30 \mathrm{~cm}$ thick layer (scenario 2) will only to a very limited degree cause delay. It would take only 10.2 year for mecoprop to reach the groundwater (bottom of profile), 10.7 year for isoproturon and 11.0 year for acetochlor (Fig. 4). However, the mineralization in the layer would remove approximately $24 \%$ mecoprop, $10 \%$ isoproturon and $3 \%$ acetochlor. The heterogeneous limestone could contain several active layers or one thicker layer. This may be realistic since the limestone settings in the field site are more than $30 \mathrm{~m}$ thick in $61 \%$ and less than $10 \mathrm{~m}$ thick in $7 \%$ of the surface of the catchment (Morvan et al., 2006). Assuming the summed extent of active layers to be $1 \mathrm{~m}$ over the whole $10 \mathrm{~m}$ profile (scenario 3), then the breakthrough times would be 10.6 years (mecoprop), 12.4 years (isoproturon) and 13.3 years (acetochlor) respectively, and the proportion of mineralized herbicide would then become 59 \% mecoprop, $31 \%$ isoproturon and only $9 \%$ acetochlor (Fig. 4). 
In conclusion, if only one active layer of $30 \mathrm{~cm}$ thickness is present pr $10 \mathrm{~m}$ the retardation due to sorption will be negligible for all three herbicides and the removal will negligible for acetochlor but not for isoproturon and mecoprop, whereas the effect of both retardation and removal will be notable for all three herbicides if the layer is 3 times thicker.

411 Considering the thickness of unsaturated limestone in the investigated field site is up to $42 \mathrm{~m}$ thick it is not unlikely that the summed extend of an active layer will be greater than the observed $30 \mathrm{~cm}$. Hence the importance of such active layers in the unsaturated limestone depends on their magnitude and consequently a very detailed knowledge of the limestone characteristics of the site is paramount.

\section{Conclusions}

Within few centimeters small scale vertical variability was present beyond measuring and sampling uncertainties showing clear shifts in sorption and microbial activity in both heterogeneous unsaturated limestone and sandy aquifer. None of the investigated parameters (TOC; TIC; specific surface area; sand, silt and clay content; water content; $\mathrm{pH}_{\mathrm{w}}$ ) individually could explain the variations. These variations followed a color shift or a color gradient in the core section.

The significance of these layers, or ecotones, with increased sorption and microbial mineralization depends on the specific herbicide and the extent of these layers, and it is therefore important to determine this. Such a detailed knowledge will improve the predictions of herbicide fate in the catchment if the geology is well described and included in reactive geochemical models.

\section{Acknowledgement}


this study together with the Technical University of Denmark (DTU). ${ }^{14} \mathrm{C}$-labelled acetochlor

432

433

434

435

436

437

438

439

440

441

442

443

444

445

446

447

448

449

450

451

452

453

454

455

456

457

458

459

460

461

462

463

464

was kindly provided by Dow Agroscience. The authors thank Ellinor Lindberg and Mona

Refstrup for laboratory assistance, and Torben Dolin for the graphic assistance. Also thank to

Bolette Nygaard and BRGM who took active part during drilling at Brévilles, and Alexis

Gutierrez and Nicole Baran for always being helpful.

\section{References}

Albrechtsen, H.-J., Mills, M.S., Aamand, J., Bjerg, P.L., 2001. Degradation of herbicides in shallow Danish aquifers: an integrated laboratory and field study. Pest Manag. Sci. 57, 341-350.

Battaglin, W.A., Furlong, E.T., Burkhardt, M.R., Peter, C.J., 2000. Occurrence of sulfonylurea, sulfonamide, imidazolinone, and other herbicides in rivers, reservoirs and ground water in the Midwestern United States, 1998. Sci. Total Environ. 248, 123-133.

Bending,G.D., Lincoln,S.D., Sorensen,S.R., Morgan,J.A.W., Aamand,J., Walker, A., 2003. In-field spatial variability in the degradation of the phenyl-urea herbicide isoproturon is the result of interactions between degradative Sphingomonas spp. and soil $\mathrm{pH}$. Appl. Environ. Microb. 69, 827-834.

Bending, G.D., Rodriguez-Cruz, M.S., 2007. Microbial aspects of the interaction between soil depth and biodegradation of the herbicide isoproturon. Chemosphere. 66, 664671.

Bending, G.D., Shaw, E., Walker, A., 2001. Spatial heterogeneity in the metabolism and dynamics of isoproturon degrading microbial communities in soil. Biol. Fert. Soils. 33, 484-489.

Besien, T.J., Williams, R.J., Johnson, A.C., 2000. The transport and behaviour of isoproturon in unsaturated chalk cores. J. Contam. Hydrol. 43, 91-110.

Bigham, J.M. (Editor-in-Chief) et al., 1996. Methods of Soil Analysis. Part 3 Chemical Methods. Soil Science Society of America, Inc. and American Society of Agronomy, Inc., Madison, Wisconsin, USA.

Charnay, M.P., Tuis, S., Coquet, Y., Barriuso, E., 2005. Spatial variability in C-14-herbicide degradation in surface and subsurface soils. Pest Manag. Sci. 61, 845-855.

Clausen, L., Fabricius, I., 2001. Atrazine, isoproturon, mecoprop, 2,4-D, and bentazone adsorption onto iron oxides. J. Environ. Qual. 30, 858-869.

Clausen, L., Fabricius, I., Madsen, L., 2001. Adsorption of pesticides onto quartz, calcite, kaolinite, and alpha-alumina. J. Environ. Qual. 30, 846-857. 
Clausen, L., Larsen, F., Albrechtsen, H.-J., 2004. Sorption of the herbicide dichlobenil and the metabolite 2,6-dichlorobenzamide on soils and aquifer sediments. Environ. Sci. Technol. 38, 4510-4518.

Coquet, Y., Ribiere, C., Vachier, P., 2004. Pesticide adsorption in the vadose zone: a case study on Eocene and Quaternary materials in Northern France. Pest Manag. Sci. 60, 992-1000.

Curiale, 2000. MPN Calculater [Build 24], Software program. http://members.ync.net/mcuriale/mpn/index.html.

de Lipthay, J.R., Tuxen, N., Johnsen, K., Hansen, L.H., Albrechtsen, H.-J., Bjerg, P.L., Aamand, J., 2003. In situ exposure to low herbicide concentrations affects microbial population composition and catabolic gene frequency in an aerobic shallow aquifer. Appl. Environ. Microb. 69, 461-467.

European Parliament and Council, 2006. Directive 2006/118/EC of the European Parliament and of the Council of 12 December 2006 on the protection of groundwater against pollution and deterioration.

Fomsgaard, I.S., 1995. Degradation of Pesticides in Subsurface Soils, Unsaturated Zone - A Review of Methods and Results. Int. J. Environ. An. Ch. 58, 231-245.

Fredslund, L., Vinther, F.P., Brinch, U.C., Elsgaard, L., Rosenberg, P., Jacobsen, C.S., 2008. Spatial variation in 2-methyl-4-chlorophenoxyacetic acid mineralization and sorption in a sandy soil at field. J. Environ. Qual. 37, 1918-1928.

Goldscheider, N., Hunkeler, D., Rossi, P., 2006. Review: Microbial biocenoses in pristine aquifers and an assessment of investigative methods. Hydrogeol. J. 14, 926-941.

Gonod, L.V., Chenu, C., Soulas, G., 2003. Spatial variability of 2,4-dichlorophenoxyacetic acid (2,4-D) mineralisation potential at a millimetre scale in soil. Soil Biol. Biochem. 35, 373-382.

Gutierrez, A., Baran, N., 2009. Long-term transfer of diffuse pollution at catchment scale: Respective roles of soil, and the unsaturated and saturated zones (Brevilles, France). J. Hydrol. 369, 381-391.

Haria, A.H., Hodnett, M.G., Johnson, A.C., 2003. Mechanisms of groundwater recharge and pesticide penetration to a chalk aquifer in southern England. J Hydrol, 275, 122-137.

Heron, G., Barcelona, M.J., Andersen, M.L., Christensen, T.H., 1997. Determination of nonvolatile organic carbon in aquifer solids after carbonate removal by sulfurous acid. Ground Water 35, 6-11.

Hiller, E., Cernansky, S., Krascsenits, Z., Milicka, J., 2009. Effect of soil and sediment composition on acetochlor sorption and desorption. Environ. Sci. Pollut. R. 16, 546554.

ISO 7827, 1984. Water quality-evaluation in an aqueous medium of the "ultimate" aerobic biodegradability of organic compounds-methods by analysis of dissolved organic carbon (DOC). International Organization for Standardization. 
Jacques, D., Mouvet C., Mohanty, B., Vereecken, H., Feyen, J., 1999. Spatial variability of atrazine sorption parameters and other soil properties in a podzoluvisol. J. Contam. Hydrol. 36, 31-52.

Janniche, G., Lindberg, E., Mouvet, C., Albrechtsen, H.-J. Distribution of isoproturon, mecoprop and acetochlor mineralization and mineralizers in deep unsaturated limestone and sandy aquifer. Chemosphere submitted.

Jensen, P.H., Hansen, H.C.B., Rasmussen, J., Jacobsen, O.S., 2004. Sorption-controlled degradation kinetics of MCPA in soil. Environ. Sci. Technol. 38, 6662-6668.

Johnson, A.C., Hughes, C.D., Williams, R.J., Chilton, P.J., 1998. Potential for aerobic isoproturon biodegradation and sorption in the unsaturated and saturated zones of a chalk aquifer. J. Contam. Hydrol. 30, 281-297.

Johnson, A.C., White, C., Bhardwaj, C.L., 2000. Potential for isoproturon, atrazine and mecoprop to be degraded within a chalk aquifer system. J. Contam. Hydrol. 44, 1-18.

Kolpin, D.W., Kalkhoff, S.J., Goolsby, D.A., Sneck-Fahrer, D.A., Thurman, E.M., 1997. Occurrence of selected herbicides and herbicide degradation products in Iowa's ground water, 1995. Ground Water 35, 679-688.

Kristensen, G.B., Johannesen, H., Aamand, J., 2001. Mineralization of aged atrazine and mecoprop in soil and aquifer chalk. Chemosphere 45, 927-934.

Larsen, L., Sorensen, S.R., Aamand, J., 2000. Mecoprop, isoproturon, and atrazine in and above a sandy aquifer: Vertical distribution of mineralization potential. Environ. Sci. Technol. 34, 2426-2430.

Lehmicke, L.G., Williams, R.T., Crawford, R.L., 1979. C-14-Most-Probable-Number Method for Enumeration of Active Heterotrophic Microorganisms in Natural-Waters. Appl. Environ. Microb. 38, 644-649.

Lengyel, Z. Foldenyi, R., 2003. Acetochlor as a soil pollutant. Environ. Sci. Pollut. R. 10, 1318.

Ma, Q.L., Rahman, A., Holland, P.T., James, T.K., McNaughton, D.E., 2004. Field dissipation of acetochlor in two New Zealand soils at two application rates. J. Environ. Qual. 33, 930-938.

Madsen, L., Lindhardt, B., Rosenberg, P., Clausen, L., Fabricius, I., 2000. Pesticide sorption by low organic carbon sediments: a screening for seven herbicides. J. Environ. Qual. 29, 1488-1500.

Mathias, S.A., Butler, A.P., McIntyre, N., Wheater, H.S., 2005. The significance of flow in the matrix of the Chalk unsaturated zone. J Hydrol, 310, 62-77.

Mills, M.S., Hill, I.R., Newcombe, A.C., Simmons, N.D., Vaughan, P.C., Verity, A.A., 2001. Quantification of acetochlor degradation in the unsaturated zone using two novel in situ field techniques: comparisons with laboratory-generated data and implications for groundwater risk assessments. Pest Manag. Sci. 57, 351-359. 
Morvan, X., Mouvet, C., Baran, N., Gutierrez, A., 2006. Pesticides in the groundwater of a spring draining a sandy aquifer: Temporal variability of concentrations and fluxes. J. Contam. Hydrol. 87, 176-190.

Mouvet, C., Albrechtsen, H.-J., Baran, N., Chen, T., Clausen, L., Darsy, C., Desbionne, S., Douguet, J.M., Dubus, I.G., Fialkiewicz, W., Gutierrez, A., Haverkamp, R., Herbst, M., Howles, D., Jarvis, N.J., Jørgensen, P.R., Larsbo, M., Meiwirth, K., Mermoud, A., Morvan, X., Normand, B., O'Connor, M., Ritsema, C., Roessle, S., Roulier, S., Soutter, M., Stenemo, F., Thiery, D., Vachaud, G., Vereecken, H., Vischetti, C., 2004. PEGASE. Pesticides in European Groundwaters: detailed study of representative quifers and Simulation of possible Evolution scenarios. Dubus I.G. and C. Mouvet (Editors). Final report of the European project \#EVK1-CT1990-00028. BRGM/RP52897-FR, 358 p.

OECD, 1993. OECD guidelines for testing of chemicals.106 Adsorption/desorption Paris, France.

Pedersen, P. G., 2000. Pesticide degradability in groundwater: Importance of redox conditions. Ph.D.Thesis, 1-67. Department of Environmental Science and Engineering, Technical University of Denmark, Kgs. Lyngby, Denmark.

Thorling, L. (ed.), 2009. Grundvandsovervågning 2008 (Groundwater surveillance 2008). GEUS, Denmark. [in Danish]

Tomlin, C.D.S. (editor), 1997. The Pesticide Manual, Eleventh ed. British Crop Protection Council, UK.

Turner, J., Albrechtsen, H.-J., Bonell, M., Duguet, J.P., Harris, B., Meckenstock, R., McGuire, K., Moussa, R., Peters, N., Richnow, H.H., Sherwood-Lollar, B., Uhlenbrook, S., van Lanen, H., 2006. Future trends in transport and fate of diffuse contaminants in catchments, with special emphasis on stable isotope applications. Hydrol. Process. 20, 205-213.

Tuxen, N., Tuchsen, P.L., Rugge, K., Albrechtsen, H.-J., Bjerg, P.L., 2000. Fate of seven pesticides in an aerobic aquifer studied in column experiments. Chemosphere 41, $1485-1494$.

Vinther, F.P., Brinch, U.C., Elsgaard, L., Fredslund, L., Iversen, B.V., Torp, S., Jacobsen, C.S., 2008. Field-scale variation in microbial activity and soil properties in relation to mineralization and sorption of pesticides in a sandy soil. J. Environ. Qual. 37, 17101718.

Walker, A., Bromilow, R.H., Nicholls, P.H., Evans, A.A., Smith, V.J.R., 2002. Spatial variability in the degradation rates of isoproturon and chlorotoluron in a clay soil. Weed Res. 42, 39-44.

Walker, A., Jurado-Exposito, M., Bending, G.D., Smith, V.J.R., 2001. Spatial variability in the degradation rate of isoproturon in soil. Environ. Pollut. 111, 407-415.

Wellings, S.R., 1984. Recharge of the Upper Chalk Aquifer at A Site in Hampshire, England 1. Water-Balance and Unsaturated Flow. J Hydrol, 69, 259-273. 
583

584

585

Wood, M., Issa, S., Albuquerque, M., Johnson, A.C., 2002. Spatial variability in herbicide degradation in the subsurface environment of a groundwater protection zone. Pest Manag. Sci. 58, 3-9. 